\title{
INFLUENCE OF COMPUTER BASED TEST (CBT) EXAMINATION ON ACADEMIC PERFORMANCE OF ENGINEERING STUDENTS IN NIGERIAN UNIVERSITIES
}

\author{
EGOIGWE SOCHIMA VINCENT ${ }^{1}$, MADUCHIOMA VIVIAN ${ }^{2}$, MAMAH NNEDINKPA VALERIA ${ }^{3}$, \\ CHUKWUEMEKA JOSEPH CHUKWU ${ }^{4}$, KALU-MBA EVELYN ${ }^{5}$, NWEKE PRINCE ONYEMAECHI ${ }^{6}$ \\ \& EDWARD C. ANOLIEFO ${ }^{7 *}$ \\ ${ }^{1,3,7}$ Department of Electronic Engineering, University of Nigeria, Nsukka, Nigeria \\ ${ }^{2,4}$ Department of Educational Foundations, University of Nigeria, Nsukka \\ ${ }^{5}$ Department of Educational Management and Business Studies, Federal University, Ekiti State, Nigeria \\ ${ }^{6}$ Institute of Education, University of Nigeria, Nsukka
}

\begin{abstract}
The study examined the influence of Computer Based Test (CBT) examination on academic performance of engineering students in Nigerian Universities. The study adopted a descriptive survey design. Two research questions guided the study. The population of the study comprised 1, 225 undergraduates and academic lecturers in the Faculty of Engineering, University of Nigeria, Nsukka. The study sampled $20 \%$ of the total population which is 245 , comprising 160students and 85 academic lecturers selected through random sampling technique. The instrument for data collection was structured questionnaire developed by the researchers. The instrument was validated by three experts in the University of Nigeria, Nsukka. Cronbach Alpha method was used to determine the reliability of the instrument. The reliability of the instrument was estimated at 0.78 which was considered reliable enough for the study. The findings of the study revealed the challenges militating against $\mathrm{CBT}$ examination on academic performance of engineering students in Nigerian Universities, such as irregular power supply during CBT examination, irregular time-table for CBT exams, time durations affect some students who are not computer literate, lack of qualified ICT officers attached to the CBT centre and poor network leading to some student's inability to finish their CBT examination. The findings of the study also revealed some benefits of $\mathrm{CBT}$ examinations on academic performance of engineering students in Nigerian Universities. Based on the findings of the study, it was recommended among others that academic lecturers should take up the pattern of external examinations by exposing the students to CBT examination in the internal examinations to lessen examination anxiety.
\end{abstract}

KEYWORDS: Academic Performance, Computer-Based-Test, Engineering Students \& Examination

Received: Jun 09, 2020; Accepted: Jun 29, 2020; Published: Jun 30, 2020; Paper Id.: IJMPERDJUN2020481

\section{INTRODUCTION}

Student's academic performance in the universities can be assess in different conduct, but in a developing country like Nigeria where about 30 percent of the students population is illiterate, conceivably parents use the academic performance of their children in the universities to pass decision on the schools and the lecturers (Nwagwu, 2002). Studies by Alabi, Issa and Oyekunle (2012) posited that many issues affect the academic performance of students at the university. Similarly, a host of scholars like Emunemu (2000) are of the opinion that all kinds of experiences are educative, whether in or outside university system and thus, influence the academic performance of the students especially when involves the use of Computer Based Test (CBT) software. However, studies in socio-economic 
status and motivation showed that parental motivation and parent's socio-economic status have positive effect on students' academic performance in the university. Therefore, the qualities of intake also influence the quality of output and performance of students at the university. Other factors that affect the academic performance of the students also include: students enrolment (Alabi 2001), school location (Adepoju 2001), age of the student and adequacy of human material, physical and financial resources.

Computer Based Test (CBT) is a form of assessment in which thecomputer is an integral part of question papers“delivery, response storage, marking of responseor reporting of results from a test or exercise”(Whittington, Bull \& Danson, 2000). It can be amultiple choice question based examinationsystem that provides an easy use in environmentfor to test students appearingfor the examination. The main objective of Computer Based Test (CBT) isto provide all the features that an examinationsystem must have, with the interface that donot scare its users (Baddi, 2010). Computer based test examination requires a system of interconnected computer networks that the Standard Internet Protocol Suite (SIPS) helps to serve the users. Computer systems which are used for CBT examination are made of two major components to carry out functions to deliver examination questions stored and to allow students to access the questions (Williams, 2007). Furthermore, Bennett (2015) asserted that computer-based test represents a modern way of answering an examination questions, replacing the written pen and paper (PNP) format. Operationally, Computer Based Test is a grouping of networks, hardware and software which serve as a means of communication that allows the processing andmanagingof data and information. It can be understood to be a complex of non-natural method for problems solving without the use of pen and pencil.

Scholars like Newhouse(2013) posited that a Computer-Based Testingcould be delivered on a stand-alone personalcomputer, within an isolated Local AreaNetwork (LAN) or through the use of onlinetechnologies such as webpages over theinternet. The author further mentioned two types of CBT Examination, such as: Linear Test: this involves a full-length examination in which the computer selectsdifferent questions for individuals withoutconsidering their performance level.Adaptive Test: this process allows the computer to selects the rangeof questions based on individuals performancelevel. These questions are taken from a verylarge pool of possible questions categorized bycontent and difficulty (Alabi, Issa\&Oyekunle,2012).However, the used of effectiveness computer based testing system depends largely on factors such as standardization, security,examination conditions, mode of administeringthe examination, cost and so on. Al-Amri (2007) also stated that thestandardization of test administration conditionsis one of the benefits offered by CBT examination. Therefore, nomatter the size of the test-takers, CBT examination helpstest developers to set the same test conditions forall participants. Moreso, Bodmann \& Robinson (2004) in their study observed that undergraduate student's complete computer based text examination faster than the paper-based test examination. Interestingly, Jamila, Tariqb \& Shamic (2008) posited that CBT provide opportunities to measure complex formof knowledge and reasoning that is not possibleto engage and assess through traditional methods. According to Alabi, Issa \& Oyekunle (2012) inferred that human errors can be eliminated and examination malpractice eradicated when a CBT is adopted in the process of examination. Similarly, Akunyili (2010) posited that manually marked scripts were more prone to errors problems than computer marked ones which is computer based test.

Scholars like Bennett (2015) opined that actualizing computer based test examination requires a protected testing condition, one that keeps understudies from looking for answers by checking their computer hard drives, texting or messaging companions, or perusing the web. To Fagbola (2013), absence of institutionalized/brought together CBT 
improvement show alone undermines the accomplishment of the e-examination stage for continuous reception by and by. Fluck (2009) is of the sentiment that online appraisal may not be viable for assessing imagination, critical thinking capacity, basic considering, reflection, or true adapting; altogether the qualities of profound and successful learning. It is from the above viewed that Obioma (2013); Oye, Mazleena \& Iahad (2011); and Ilesanmi \& Lasisi (2015) postulated different challenges militating against CBT examination in Nigerian universitiesas highlighted, whichinclude inadequate ICT infrastructure;irregular power supply; and student's inadequate skills in ICT; and integrity of examination managers

Computer Based Tests according Daramola (2018) offer few advantages over conventional paper-and-pencil or paper-based tests. However, innovation based appraisal give chances to determine complex type of learning and thinking that is impractical to connect with conventional strategies (Alabi, Isaa, \&Oyekunle, 2012). For instance, some offices now direct inclination test for occupation searchers through electronic means; the colleges and other higher institutions are enrolling and leading electronic examination for their undergraduate students through Internet facilities and other electronic systems administration devices. Correspondingly, extraordinary examination bodies in the country such as: West Africa Examination Council (WAEC), National Examinations Council (NECO), National Business and Technical Examination Board (NABTEB), National Teachers' Institute (NTI), Joint Admissions and Matriculation Board (JAMB), Post Unified Tertiary Matriculation Examination (Post-UTME) among others enrol their candidates through electronic means (Olawale \& Shafii, 2010). Computer and related innovations give capable instruments to address the new difficulties of outlining and actualizing appraisals techniques that pass through the customary practices and encourage recording more extensive collection of psychological aptitudes and information (Mubashrah, Tariq \&Shami, 2012). Computer based on the other hand, testing can encourage the improvement of more legitimate evaluations and has the possibilities of viability and effectiveness in instructing, proficient advancement and direct criticism (Mubashrah, Tariq \& Shami, 2012). For instance, online examination has changed the instruction business which is not as usual, thus, made the fantasies of separation taking in a reality. Similarly, Daramola (2018) position that examination is no longer constrained to paper and pen organizers rather, it has gone a long way to improved measurement precision and efficiency; increased convenience for students and those who use the test scores; self-administering;providesimmediate scoring after examination; Integrateimmediate information to the database without stress;and above all, it is quicker and better than paper-test methods.

Other good reasons or benefits of CBT examination as cited by Alabi, Issa \& Oyekunle (2012) include quick release of results; generation of databank for admitted and registered students; quiet and comfortable test centres; secured test items; unbiased test administration and scoring; faster decision making; reduction in cases of impersonation and adequate coverage of course syllabus in examination questions. From the above justifications of CBT examination, there is no doubt therefore, that the use of Information and Communication Technology (ICT) today offers many new opportunities for innovation in Nigerian universities through potentially powerful scoring, reporting and real-time feedback mechanisms. One potential limitation for realizing the benefits of computer-based test in large scale testing comes in designing questions and tasks with which computers can effectively interface (i.e., for scoring and score reporting purposes) while still gathering meaningful measurement evidence. Other benefits of CBT examination towards enhancing academic performance of students in Nigerian universities as stated by Okoronkwo (2015), include creation of digital records of student growth and development which can easily be passed along from grade to grade; greater flexibility with respect to location and timing of examinations; improved reliability because machine marking is much more reliable than human marking; computerized marking does not 'know' the students and so neither favour nor witch-hunt any candidate; 
greater storage efficiency; enhanced question styles which incorporate interactivity and multimedia; question banks, randomization of questions and response orders to reduce cheating; immediate feedback can be given to the examinee; improved test security due to electronic transmission and encryption; and saves time and manpower for the test administration

Further, Daramola (2018) posited that Computer Based Test is not just an alternative method for delivering examinations or opportunities for innovation in the university system; it represents an important qualitative shift away from traditional methods examination such as paper-based tests to computer based test examination. Regardless of these advantages available in computerized test administration, it does not mean that CBTs are intrinsically better than paperand-pencil tests. Previous study by researchers have even found that testing format does not affect test scores and as such CBT can be considered a valid and acceptable testing method. As CBT began to be used for totalevaluation of academic performance of student's examinations, establishing whether computer-based testing performance was comparable to that of paper-based assessment became important.

\section{Statement of the Problem}

Scholars on Computer Based Test (CBT) examination had observed in the past years the relevant and unproblematic of carrying out CBT examination without mindful of the challenges the students are facing during CBT examinations both in the first years, general courses and final examinations. Researcher is of the viewed that the high rate of poor performance of students during or after the CBT examinations calls for alarms as students tends to query the motivation behind using CBT software to conduct examination or to gain admission in the universities in Nigerian educational system. Thus, the researchers believe that the challenges may perhaps centre on the influence of variables such as inadequacy of ICT facilities, problem of power supply, inability to operate computer effectively by the students, distance of the CBT centres to the student's departments or faculties, examination malpractices through the web-content manager who manage the database and due to unavailability of paper pencil to do some workings. The study, thus, seeks to examine the influence of computer based test examination on academic performance of engineering students in Nigerian Universities.

\section{Purpose of the Study}

The general purpose of the study is to examine the influence of Computer Based Test (CBT) examination on academic performance of engineering students in Nigerian Universities. Specifically, the study sought to:

- examine the challenges militating against CBT examination on academic performance of engineering students in Nigerian Universities?

- determine the benefits of CBT Examination on academic performance of engineering students in Nigerian Universities.

\section{Research Questions}

The following research questions guided the study:

- What are the challenges militating against CBT examination on academic performance of engineering students in Nigerian Universities?

- What are the benefits of CBT Examination on academic performance of engineering students in Nigerian 
Universities?

\section{MATERIALS AND METHODS}

This study adopted descriptive survey design. This study was carried out in the University of Nigeria, Nsukka, Enugu State, Nigeria. The population of the study comprised 1, 225 undergraduates and academic lecturers in the Faculty of Engineering, University of Nigeria, Nsukka. The study sampled 20\% of the total population which is 245, comprising 160 students and 85 academic lecturers selected through random sampling technique.The instrument for data collection was structured questionnaire developed by the researchers. The instrument was validated by three experts, two from the Department of ElectronicsEngineering, Faculty of Engineering and one from the Department of Science Education, Faculty of Education, all from the University of Nigeria, Nsukka. The instrument was structured in a 4 point rating scale of Strongly Disagree $(\mathrm{SD})=1$, Disagree $(\mathrm{D})=2$, Agree $(\mathrm{A})=3$, and Strongly Agree $(\mathrm{SA})=4$. The reliability of the instrument was estimated at 0.78 which was considered reliable enough for the study. Mean and standard deviation was used to analyze the research questions. Cronbach Alpha techniques were used to determine the internal consistency of the instrument.The criterion means score 2.50 and above was used as benchmark for acceptance since the questionnaire items were placed on four point rating scale. By this, any response with mean value of 2.50 and above was considered accepted, while any mean value that is below 2.50 was considered rejected.

\section{RESULTS AND DISCUSSIONS}

Research Question One: What are the challenges militating against CBT examination on academic performance of engineering students in Nigerian Universities?

Table 1: Mean Ratings and Standard Deviation of Responses on Challenges Militating against CBT Examination on Academic Performance of Engineering Students in Nigerian Universities

\begin{tabular}{|c|c|c|c|c|c|c|c|}
\hline \multirow[t]{2}{*}{$\mathbf{S} / \mathbf{N}$} & \multirow[t]{2}{*}{ Items Statement } & \multicolumn{3}{|c|}{$\begin{array}{l}\text { Students } \\
\mathrm{N}=160\end{array}$} & \multicolumn{3}{|c|}{$\begin{array}{l}\text { Academic Lecturers } \\
\qquad \mathrm{N}=85\end{array}$} \\
\hline & & Mean & SD & Decision & $\mathbf{M}$ & SD & Decision \\
\hline 1 & $\begin{array}{l}\text { Irregular power supply during CBT } \\
\text { examination }\end{array}$ & 2.84 & 0.57 & A & 2.66 & 0.80 & A \\
\hline 2 & Some students are not computer literate & 2.59 & 0.59 & A & 2.73 & 0.79 & A \\
\hline 3 & $\begin{array}{l}\text { Examination batching affects performance } \\
\text { in CBT exams }\end{array}$ & 2.55 & 0.59 & A & 2.51 & 0.81 & A \\
\hline 4 & Irregular time-table for CBT exams & 2.78 & 0.57 & A & 2.68 & 0.79 & A \\
\hline 5 & $\begin{array}{l}\text { Time durations affect some students who } \\
\text { are not computer literate }\end{array}$ & 2.81 & 0.57 & A & 2.59 & 0.80 & A \\
\hline 6 & $\begin{array}{l}\text { Lack of qualified ICT officers attached to } \\
\text { the CBT centre }\end{array}$ & 2.73 & 0.57 & A & 2.57 & 0.81 & A \\
\hline 7 & $\begin{array}{l}\text { Lateness to examination centre by the } \\
\text { students }\end{array}$ & 2.60 & 0.59 & A & 2.77 & 0.78 & A \\
\hline 8 & Using of faulty computers & 2.58 & 0.59 & A & 2.84 & 0.78 & A \\
\hline 9 & Poor lightning of CBT centres & 2.83 & 0.57 & A & 2.63 & 0.80 & A \\
\hline 10 & Poor location of CBT centres & 2.53 & 0.59 & A & 2.78 & 0.78 & A \\
\hline 11 & $\begin{array}{l}\text { Poor network leading to some student's } \\
\text { inability to finish their CBT exams }\end{array}$ & 2.63 & 0.58 & A & 2.90 & 0.77 & A \\
\hline 12 & $\begin{array}{l}\text { Attitude of examination supervisors and } \\
\text { invigilators }\end{array}$ & 2.72 & 0.58 & A & 2.82 & 0.78 & A \\
\hline 13 & Inadequate ICT infrastructure facilities & 2.89 & 0.56 & A & 2.77 & 0.78 & A \\
\hline 14 & $\begin{array}{l}\text { Subjective scoring and plausible } \\
\text { manipulation of results }\end{array}$ & 2.66 & 0.58 & A & 2.55 & 0.81 & A \\
\hline 15 & Late release of results and missing grades & 2.50 & 0.59 & A & 2.82 & 0.78 & $\mathbf{A}$ \\
\hline
\end{tabular}




0.58

Data presented in table 1 shows that items 1 to 15 both students and lecturers have mean scores greater than the set benchmark mean score value of 2.50 (criterion mean). In addition, the overall mean score ratings of students and lecturers on challenges militating against CBT examination on Academic performance of engineering students in Nigerian Universities are also greater than the criterion mean of 2.50. This implies that lecturers and students agree that the items listed in the table are all challenges militating against CBT examination on the Academicperformance of engineering students in Nigerian Universities. The result further shows that while students rated item 13 as the most challenging factor militating against CBT examination on the Academic performance of engineering students in Nigerian Universities, lecturers rated item 11 as the most challenging factor. In addition, the closeness of the overall standard deviation scores of the lecturers and students indicate that less variability exist between the lecturers and students rating on the challenges militating against CBT examination on the Academic performance of engineering students in Nigerian Universities.

Research Question Two: What are the benefits of CBT examination on academic performance of engineering students in Nigerian Universities?

Table 2: Mean Ratings and Standard Deviation of Responses on Benefits of CBT Examination on Academic Performance of Engineering Students in Nigerian Universities

\begin{tabular}{|c|c|c|c|c|c|c|c|}
\hline \multirow{2}{*}{$\mathbf{S} /$} & \multirow{2}{*}{ Items Statement } & \multicolumn{3}{|c|}{$\begin{array}{l}\text { Students } \\
\mathbf{N}=160\end{array}$} & \multicolumn{3}{|c|}{$\begin{array}{l}\text { Academic Lecturers } \\
\qquad \mathrm{N}=85\end{array}$} \\
\hline & & Mean & SD & $\begin{array}{c}\text { Decisi } \\
\text { on }\end{array}$ & $\mathbf{M}$ & SD & $\begin{array}{c}\text { Decisi } \\
\text { on }\end{array}$ \\
\hline 16 & $\begin{array}{l}\text { CBT increase convenience for students and those who } \\
\text { use the test scores }\end{array}$ & 2.61 & 0.58 & A & 2.58 & 0.80 & A \\
\hline 17 & CBT is self-administering & 2.70 & 0.58 & A & 2.61 & 0.80 & A \\
\hline 18 & CBT provide immediate scoring after examination & 2.82 & 0.57 & $\mathrm{~A}$ & 2.73 & 0.79 & A \\
\hline 19 & $\begin{array}{l}\text { CBT integrate immediate information to the database } \\
\text { without stress }\end{array}$ & 2.76 & 0.57 & A & 2.84 & 0.78 & A \\
\hline 20 & $\begin{array}{l}\text { CBT is quicker and better than paper and pencil test } \\
\text { methods }\end{array}$ & 2.68 & 0.58 & A & 2.88 & 0.77 & A \\
\hline 21 & CBT is quick in release of results & 2.85 & 0.57 & $\mathrm{~A}$ & 2.90 & 0.77 & A \\
\hline 22 & $\begin{array}{l}\text { CBT help to generate databank for admitted and } \\
\text { registered students }\end{array}$ & 2.79 & 0.57 & A & 2.67 & 0.80 & A \\
\hline 23 & CBT unbiased test administration and scoring & 2.63 & 0.58 & $\mathrm{~A}$ & 2.83 & 0.78 & $\mathrm{~A}$ \\
\hline 24 & CBT help to secured test items & 2.69 & 0.58 & $\mathrm{~A}$ & 2.71 & 0.79 & $\mathrm{~A}$ \\
\hline 25 & CBT is faster in decision making & 2.90 & 0.57 & A & 2.56 & 0.81 & A \\
\hline 26 & $\begin{array}{l}\text { CBT help to reduce cases of impersonation and } \\
\text { adequate coverage of course syllabus in examination } \\
\text { questions }\end{array}$ & 2.52 & 0.59 & A & 2.56 & 0.78 & A \\
\hline 27 & CBT help to score reporting purpose & 2.57 & 0.59 & A & 2.94 & 0.77 & $\mathrm{~A}$ \\
\hline 28 & $\begin{array}{l}\text { CBT create digital records of student growth and } \\
\text { development }\end{array}$ & 2.64 & 0.58 & A & 2.68 & 0.79 & A \\
\hline 29 & $\begin{array}{l}\text { CBT provide greater flexibility with respect to location } \\
\text { and timing of examinations }\end{array}$ & 2.83 & 0.57 & A & 2.74 & 0.79 & A \\
\hline 30 & CBT improved reliability than human marking & 2.84 & 0.57 & $\mathrm{~A}$ & 2.82 & 0.78 & $\mathrm{~A}$ \\
\hline 31 & CBT provide greater storage efficiency & 2.91 & 0.56 & $\mathrm{~A}$ & 2.88 & 0.77 & $\mathrm{~A}$ \\
\hline 32 & $\begin{array}{l}\text { CBT provide randomization of questions and response } \\
\text { orders to reduce cheating }\end{array}$ & 2.77 & 0.57 & A & 2.61 & 0.80 & A \\
\hline 33 & CBT provide immediate feedback to the examinee & 2.82 & 0.57 & $\mathrm{~A}$ & 2.57 & 0.81 & $\mathrm{~A}$ \\
\hline 34 & $\begin{array}{l}\text { CBT saves time and manpower for the test } \\
\text { administration }\end{array}$ & 2.90 & 0.56 & A & 2.93 & 0.77 & A \\
\hline & Cluster Mean & 2.75 & $\mathbf{0 . 5 7}$ & $\mathbf{A}$ & 2.75 & $\mathbf{0 . 7 9}$ & A \\
\hline
\end{tabular}


Data presented in table 2 shows that items 16 to 34 of both students and lecturers have mean scores greater than the set benchmark mean score value of 2.50. In addition, the overall mean score ratings of students and lecturers on benefits of CBT Examination on academic performance of engineering students in Nigerian Universities are also greater than the criterion mean of 2.50. This implies that lecturers and students agree that the items listed in the table are all benefits of CBT examination and how it enhance academic performance of engineering students in Nigerian Universities.

\section{DISCUSSIONS}

The findings of the study revealed the challenges militating against CBT examination on academic performance of engineering students in Nigerian Universities, such as irregular power supply during CBT examination, irregular time-table for CBT exams, time durations affect some students who are not computer literate, lack of qualified ICT officers attached to the CBT centre and poor network leading to some student's inability to finish their CBT exams. The findings of the study is in agreement with the findings of Obioma (2013); Oye, Mazleena \& Iahad (2011); and Ilesanmi \& Lasisi (2015) who postulated different challenges militating against CBT examination in Nigerian universities which include inadequate ICT infrastructure facilities;irregular power supply; student's inadequate skills in ICT; and integrity of examination managers.

The findings of the study revealed the justifications benefits of CBT examination on academic performance of engineering students in Nigerian Universities.This findings is in consonance with the findings of Daramola (2018) who posited that CBT examination has taking the position of paper and pencil Examination to an extent,examination is no longer constrained to paper and pen organizers, rather it has gone a long way to improve measurement precision and efficiency; increased convenience for students and those who use the test scores; self-administering; provisionsof immediate scoring after examination; Integrate immediate information to the database without stress; and above all, quicker and better than paper and pencil test methods. The findings is also in line with the findings of Bodmann \& Robinson (2004) who opined that undergraduate students complete computer based text examination faster than the paperbased test examination. The findings is also in agreement with Alabi, Issa \& Oyekunle (2012) who posited benefits of CBT examination for undergraduate students, which include quick release of results; generation of databank for admitted and registered students; quiet and comfortable test centres; secured test items; unbiased test administration and scoring; faster decision making; reduction in cases of impersonation; and adequate coverage of course syllabus in examination questions.

\section{CONCLUSIONS}

The findings from the research study have merely draw attention that Computer Based Test (CBT) examination is a means of scrutinizing academic performance of undergraduate students in Nigerian Universities is not well footed, thus, call for urgent attention in the challenge areas that was criticaldiscussed in the study. With the above findings, it is not obvious to say that potentials and prospectsimprovementof Information and Communication Technology software in Nigerian universities educational system is perhaps centre on computer and internet facilities. Therefore, the end resultof these challenges is as a result of lack of technological equipments and lack of qualified resource persons in the areas of engineering, computer science, engineering and other related areas. Therefore, the university authorities, policy makers and stakeholders are thus,likely to do greatly to invalidateor reverse the position of Information and Communication Technology (ICT) to enhance the use of Computer Based Test examination in Nigerian Universities.

\section{RECOMMENDATIONS}

Based on the findings of the study, the following recommendations were made: 
- Lecturers should take up the pattern of the external examinations by exposing the students to CBT in the internal examinations to lessen examination anxiety.

- University authorities should recruit highly skilled computer analysts, computer engineersor instructors to help improve the computer skills of students in various universities in Nigeria.

- Government should provide ICT facilities in all Nigerian universities to enhance teaching and learning among the students.

- Academic lecturers should be more committed with the use of ICT tools, giving the importance of practical knowledge in it.

- Adequate funds should be accessible for the provisions of ICT tools in Nigerian universities.

\section{REFERENCES}

1. Adepoju, M. 2001. e-Education in Nigeria: Challenges and prospects. Paper presented at the 8th UN ICT Task Force Meeting, Dublin, Ireland, April 13 - 15 Baddi, F. P. 2010. Education technology helps unite school communities, improve academic achievement T.H.E. Journal, 31(10), 46-48.

2. Alabi, A. T., \& Issa, A. O. and Oyekunle, R. 2012.The use of Computer Based Testing Method for the Conduct of Examinations at the University of Ilorin.International Journal of Learning and Development, 2(3), 68 - 80. Doi: 10.5296/ijld.v2i3.1775

3. Alabi, L. 2001. Helping Students Adapt to computer-based encrypted examinations. Educause Quarterly, 3:41 - 46

4. Al-Amri, A. 2007.Differences in rate of response to Web-based surveys among College students. International Journal on ELearning, 7(2), 265-281. Retrieved from: http://search.ebscohost.com

5. Agarana, M. C., and A. I. Ehigbochie."Optimization of Student's Academic Performance in a World-Class University Using Operational Research Technique." International Journal of Mathematics and Computer Applications Research 5.1 (2015): 4350.

6. Bennett, R. E. 2015. The Changing Nature of Educational Assessment.Review of Research in Education, 39(1), 370407.Doi: $10.3102 / 0091732 \times 14554179$

7. Bodmann, K.O. \& Robinson, Z.2004. Acceptance of internet-based learning medium: The role of extrinsic and intrinsic motivation. Information \& Management,42(8), 1095-1104. Doi:10.1016/j.im.2003.10.007

8. Daramola, F. O. 2018. Impact of computer based test in Nigeria tertiary institutions: a theoretical view. International Journal for Innovative Technology Integration in Education, 109 - 116.

9. Eтипети, S. O. 2000. Assessing the impact of examination malpractices on the measurement of ability in Nigeria.International Journal of Social Scienceand Education, 2(4), 748 - 757

10. Fagbola, T. M., Adigun, A. A., and Oke, A. O. 2013.Computer-Based Test (cbt) System for University Academic Enterprise Examination.International Journal of Scientific \& Technology Research, 2(8), 336 - 342. Retrieved from: http://www.sciepub.com/reference/127010

11. Fehintola, J. O. 2018. Assessment of challenges of CBT among students in Nigerian educational system. KIU Journal of Social Sciences, 4(2), 141-149. Retrieved from: 〈http://www.ijhumas.com/ojs/index.php/kiujoss/article/view/341〉

12. Fluck, A., Pullen, D. and Harper, C. 2009. Case Study of a Computer Based Examination System. AustralianJournal of Educational Technology, 25(4), 509 - 523.Doi: 10.14742/ajet.1126 
13. Ilesanmi, O. A., and Lasisi, F. A. 2015. Nexus of Change Management on Organizational Performance and Survival in Nigerian Universities: A Case Study of University of Ilorin. International Journal of Business and Management Review, 3(4), 66 - 81. Retrieved from: https://www.eajournals.org/journals/international-journal-of-business-and-management-reviewijbmr/vol-3issue-4-may-2015/nexus-of-change-management-on-organisational-performance-and-survival-in-nigerianuniversities-a-case-study-of-university-of-ilorin/

14. Jamila, M., Tariq, R. H. and Shamic, P. A. 2012. Computer-Based Vs Paper Based Examinations: Perceptions of University Teachers. The Turkish OnlineJournal of Educational Technology,11(4); 371 - 381. Retrieved from: https://eric.ed.gov/?id=EJ989302

15. Newhouse, J. R. 2013. Students and information technology, 2005: Convenience, connection, control and learning. Educause Center for Applied Research. Retrieved from: www.educause.edu/ecar

16. Nwagwu, O. L. 2002. Education as an Instrument for effective national development: Which way Nigeria. Business \& Entrepreneurship Journal,2(2), 27 - 38. Retrieved from: http://www.scienpress.com/Upload/BEJ/Vol\%202_2_3.pdf

17. Nwoke, B. I.,Osuji, C. U. and Agi, U. K. 2017. Influence of Computer-Based Test (CBT) on Examination malpractice in public examinations. Journal of Research \& Method in Education Journal of Research \& Method in Education, 7(2), 80-84. Retrieved from: https://pdfs.semanticscholar.org/8dd9/324355e207c212e38adbfb0012cbbef89b2e.pdf

18. Obioma, G., Junaidu, I.and Ajagun, G. 2013. The Automation of Educational Assessment in Nigeria: Challenges and Implications for Pre-service Teacher Education. A paper presented at the 39th Annual Conference of the International Association for Educational Assessment (IAEA). Tel-Aviv, Israel. Retrieved from http://www.iaea.info.edu.pk

19. Okoronkwo, C. 2015. Appraising JAMB's Computer-Based Test. NAN Features, 9: 93. Retrieved from www.nannewsnigeria.com/

20. Olawale, C. andShafi'I, M. A. 2010. E- Exams System for Nigerian Universities with Emphasis on Security and Result Integrity. Proceedings of The Seventh International Conference on e-learning Proceedings of The Seventh International Conference on elearning for knowledge-Based Society, Thailand.Thailand.

21. Oye, N. D., Mazleena, S.and Iahad, N. A. 2011. Challenges of E-learning in Nigerian University Education Based on the Experience of Developed Countries.International Journal of Managing Information Technology, 3(2), 39 4.Doi: 10.5121/ijmit.2011.3204

22. Rudio, Virginia. "Performance of teacher education graduates, DMMMSU-NLUC, Philippines in the licensure examination CY 2011 to 2013." International Journal of Educational Science and Research (IJESR) 6.3 (2016).

23. Shih-Feng, Tseng."The Study of the Phenomenon of Fangliao Immigrant Residents' Children Getting Better Academic Performance in Taiwan." International Journal of Educational Science and Research (IJESR) 6.3 (2016).

24. Whittington, N. Bull, A.A. and Danson, L. 2000. Redefining roles.University e-learning contributing to Life-long learning in a networked world.E-Learning, 1:128 - 145. Retrieved from: http://www.nationmaster.com/country/ni/Internet

25. Yadav, Ramjeet Singh, and P. Ahmed."Academic performance evaluation using fuzzy C-means." Int. J. Comput. Sci. Eng. Inf. Technol. Res 2.4 (2012): 55-84. 
